كالم يوشد لباسن خون بافته را

كا زير كشد خصم زبون يافته را

با سنكدلان شعلغخو، سختى كن

بردلر به أهن، أهن نافته را

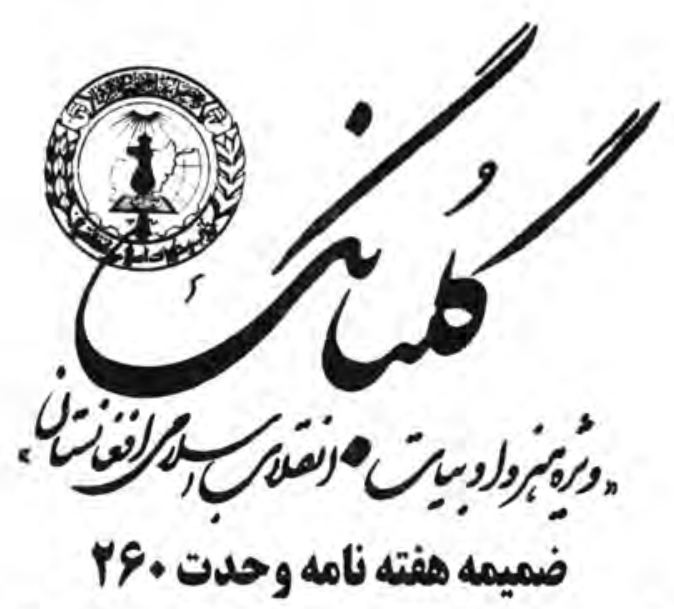
• بيدل

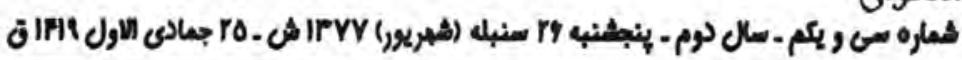

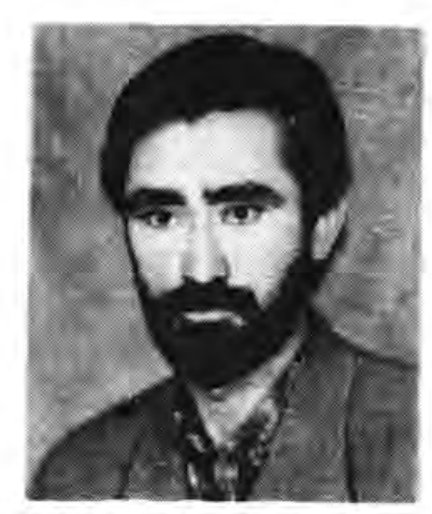

• همده جيز راريو دندا حتى استخوان ن
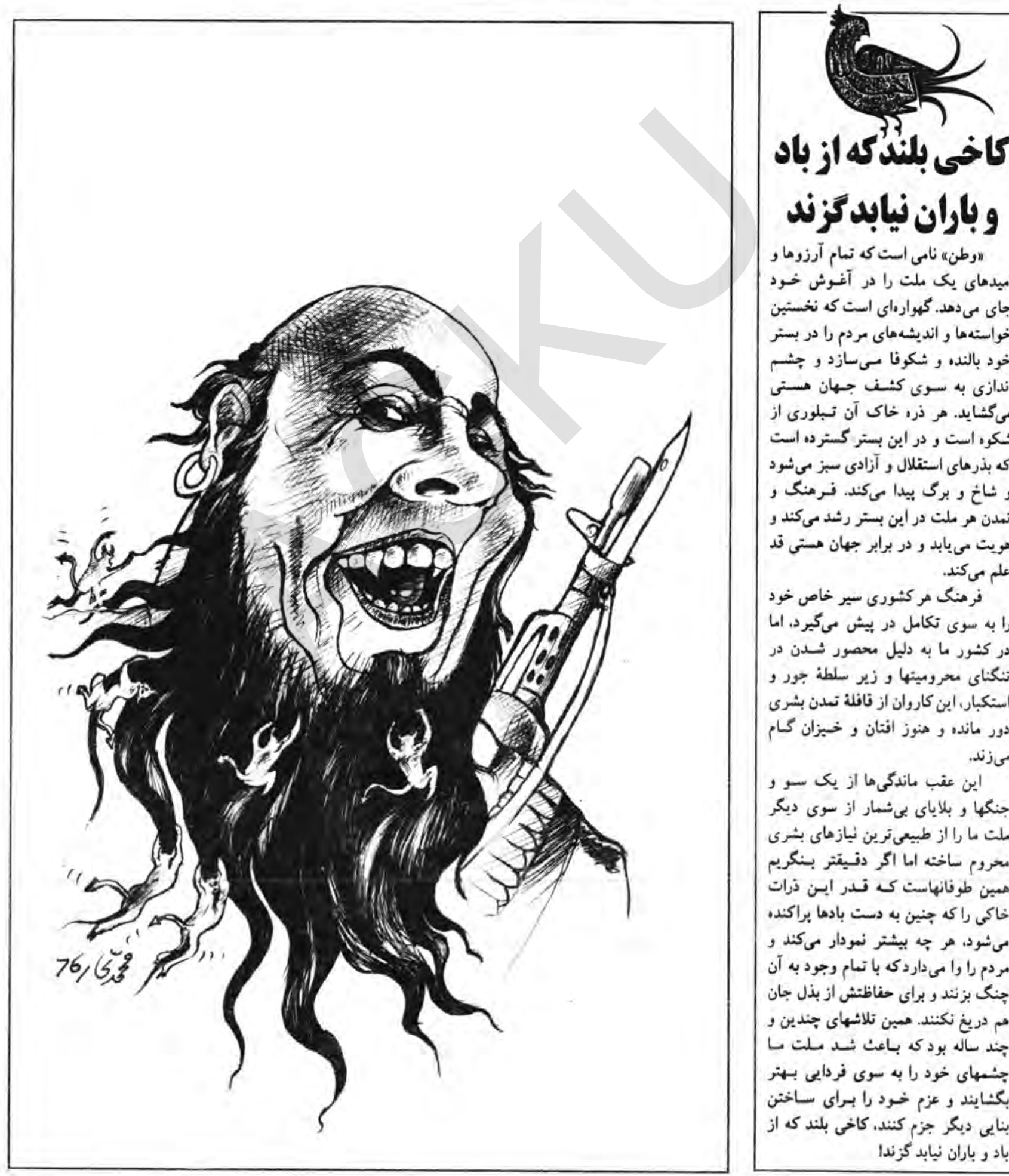

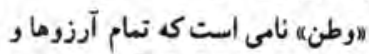

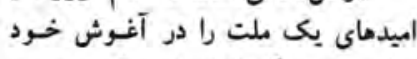

جاى مىدهد. كهوارماى است كى نخستين

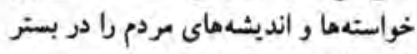

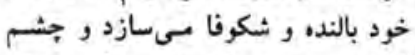

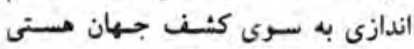

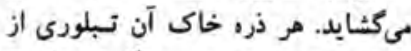

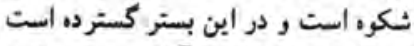

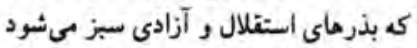

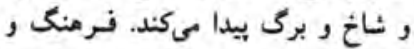

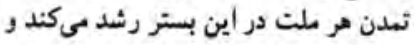

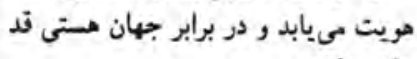

علم بىكند.

فرهنك هر كثبورى سير خاص خود

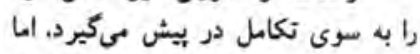

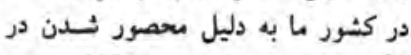

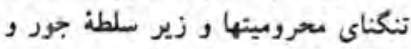

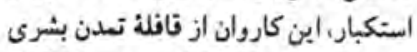

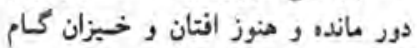

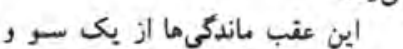

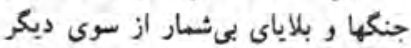

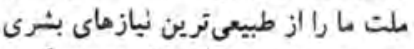

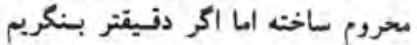

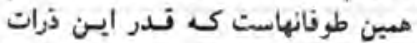
خاكى راكه جنين به دست بادها براكند.

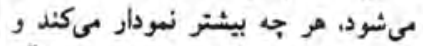

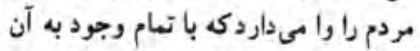

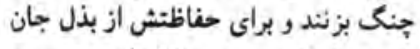

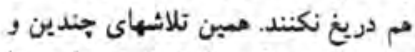

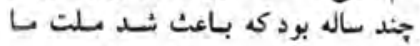

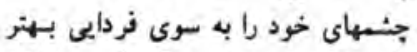

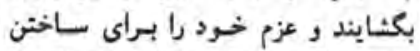

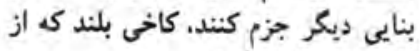
باد و باران نيابد كزئدا 


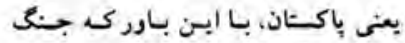

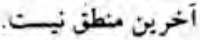

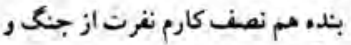

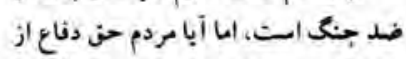
كثورخود راندارد؟ در رابط با جنكهانى

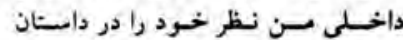

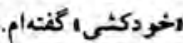

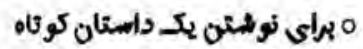

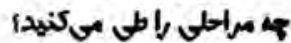

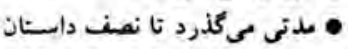

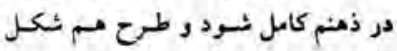

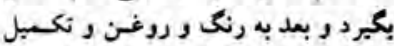

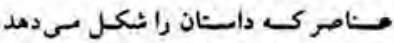

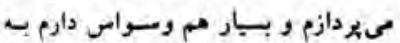

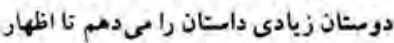
نظر نمايند.

ماز نويمندكان داخل كثور كدام

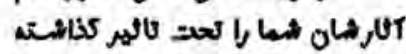

استص

• سال 19 \$كى مالهاي أغناز كار

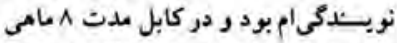

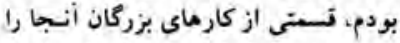

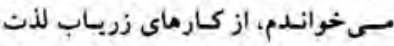

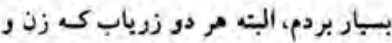

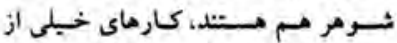
دومتان آنجا سسطحى ور تبلينى بـود نائا

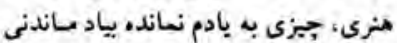
بودذ هم سمبار است.

ماز مبان داهـانهاى خودلن براي كدام يك عرف جبين بيثنتر \{xlaice,

• البثه برخلان تصور شيسا كارياي

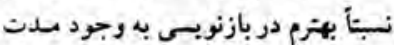

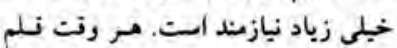

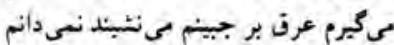

م هـا در زمبانى بـ داستخان

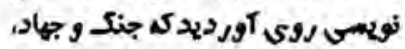
كه و كاله לرلوال دالهت. با توجه بـ

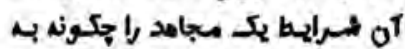

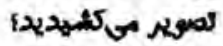
• آذ زمان مجاهد وجودن جلهابع

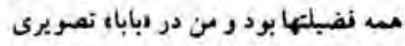

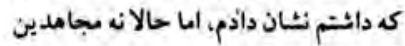

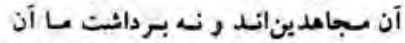

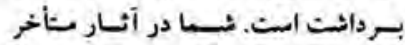
مى توانيد تعوير ديكرى با بثكربد.

غير مستولانه بـادوستان و خسصوصى

دمسازى و مسسازى با يكى از يـشعامان

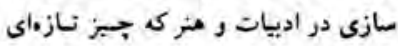

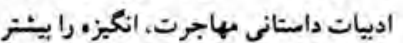

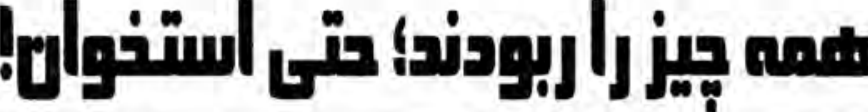

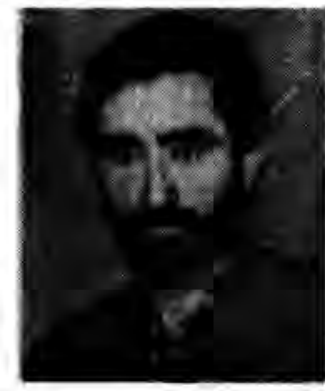

مصاحبه با نو سسنده

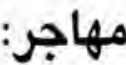

طالب حسين موحد

بود، باعث أيجاد وتفه دركار و دلبردى

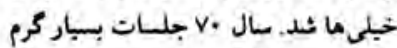
بـود و دومستـان زيـادى در جــلسيات

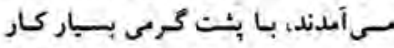

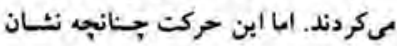

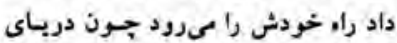

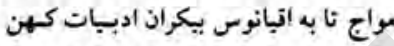
درى بـهيوندد و درخت تسومند ادبيات ـاجرت مبجنان بر بار سابي بر ادبيات

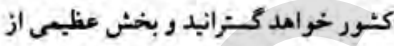

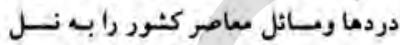
أيند. و اديات وردات آيند. متقلز خوامد ركرد.

م ا توجه به كذشت دوران الشغال

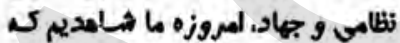

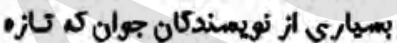

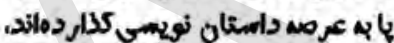

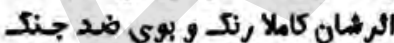

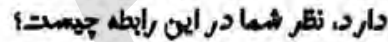

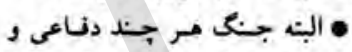

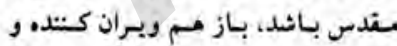

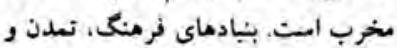

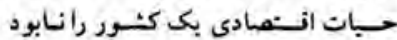

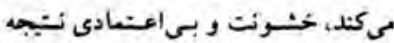

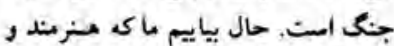

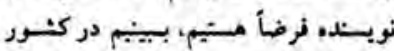

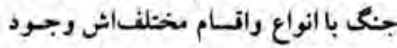
دارد. دلالان خارجى بأكرم نكهـدائستن

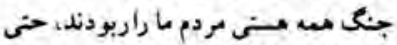
ايتخوان كسنكان ما را در بازار بإكستان

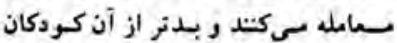

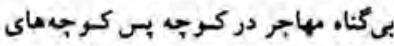

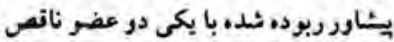

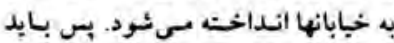

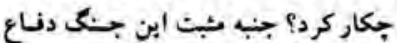

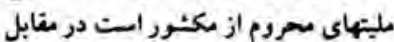

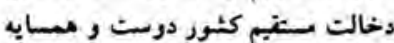

كرد، در دو اتاق كه بنجر بماى روبسروى

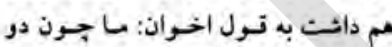
دريجه بوبروى هم

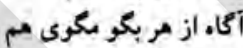

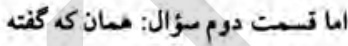

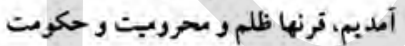

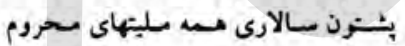
كثور را از تعام حفوق و مزاياى انسانى تحروم كرده بود، زمسانى كـ ادبيات

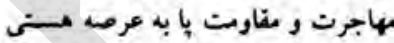

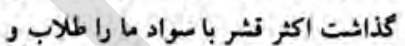

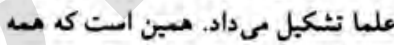

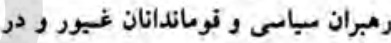
اخير نويسندكان، منر مثداذ شاعر از معين

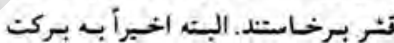
سكــونت طـولانى سهاجرين در ايسران.

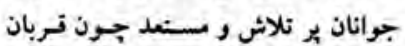

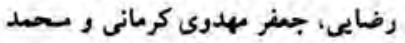

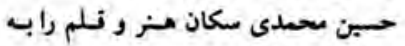

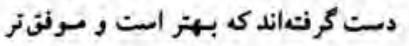

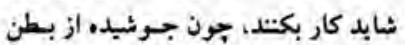

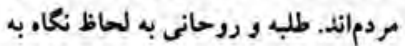

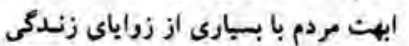

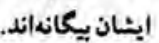

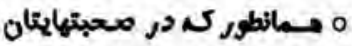
الهار م دالهتيد، لبعا از كسانى همتيد

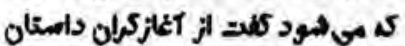
مجرت يوديد، هـروع و ادامس الهم حركت اديى را در وادى اديهات كئ

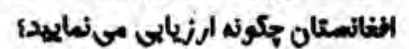

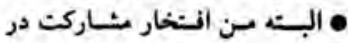
شروع اين حركت را دارم و ثمروع بـباد

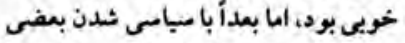

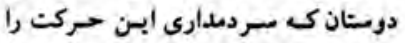

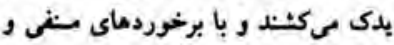

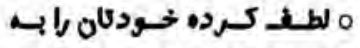

خواتندكام كلبانك معرفى نمايديد. • بـ نأن حكيم سخن در زبان آنرين.

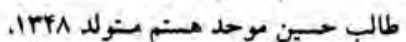

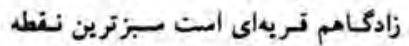

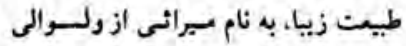

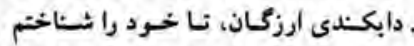
كثروى دائتم زير جكسعاي أشفالكران

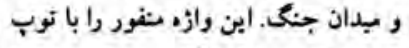

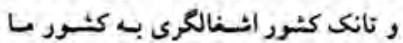

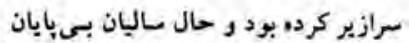

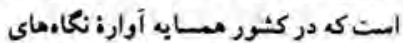
حفارتم ودر تمام اين مالهادود، آتش و وركا

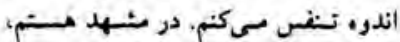

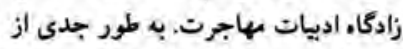

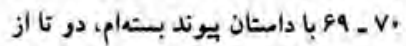
نوئتهايم در سجسوعه جهارم حسوز.

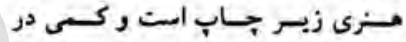

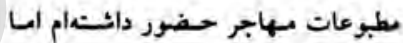

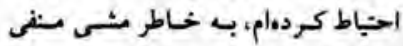
بعفى از نشريات مطلب نداده جز شنث

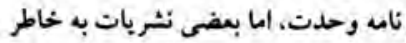

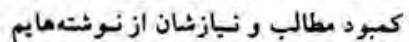
استفاد.كر دئند.

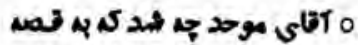

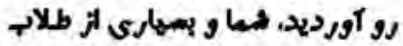

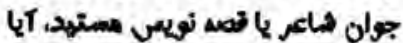
علت خامى دار وأ

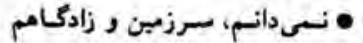

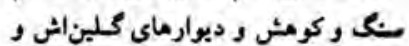
تاريخ بـر نشراز و نشيباش و و مردمان مركث و تصس مازش مس سابئكار و

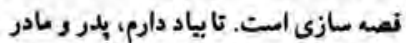

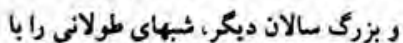

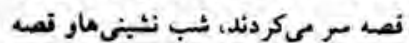

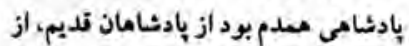
غارت انكليس از ظلم كوجىما و صدها

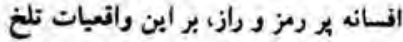

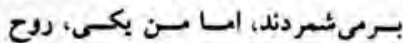

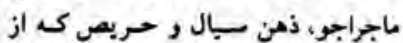

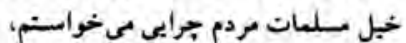

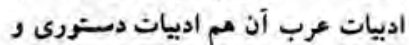
منداري منطق و امسول مستداول حسوزه

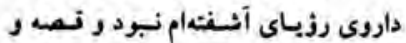
دامتان شابد كبى با مس اين خالبكا.ها

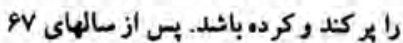

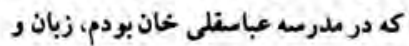
وميليلى براى بيان بهتر مىخواستم و بـانيا

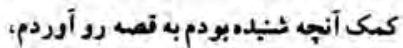


مخدىى. اما أز لهاظ فرم و مختوى سي

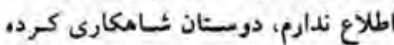

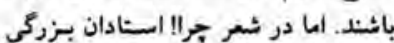

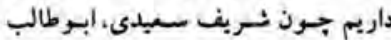

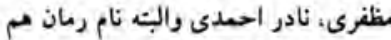

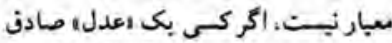
جوبك نوئنت، مسان نسوبسند، بعاصر هاسـت جون

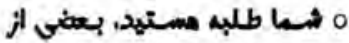

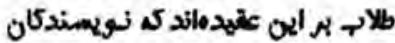
جوان تعهد ندارئد، جـون الز عندئن

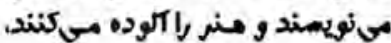

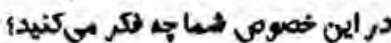

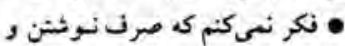

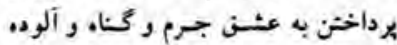

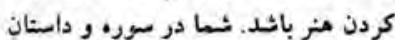

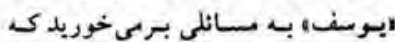
كماكان از عسّن سخن رنته، عثن زيليخا

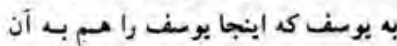

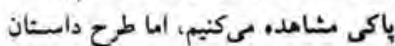

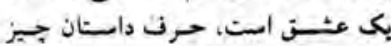

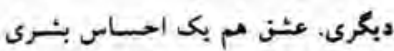

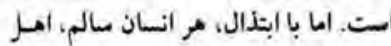

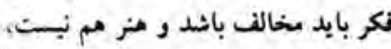

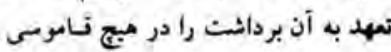
نسىيابيد.

م ألر يرخى از نومسندكان در

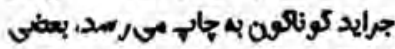

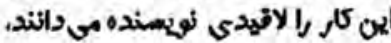

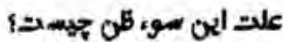
• اين فكر شايد درست نبائد، كار

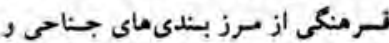

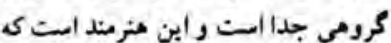

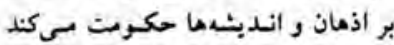

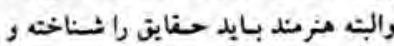

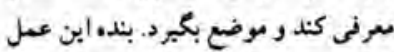

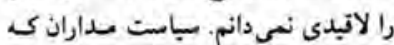
مسركز تسحسل مسعديكر و جـاب نسطر

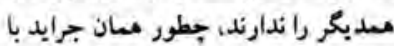

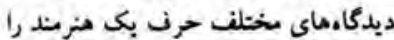

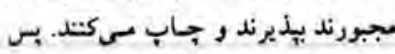

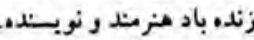

O الى موحد در الخر آكر خحود

هماكي خامى داريد بهرمايند. •

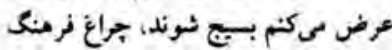

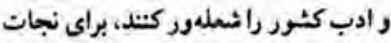

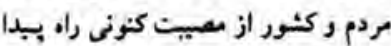

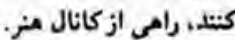

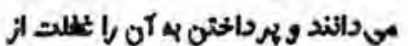

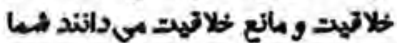

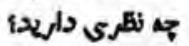
• بن ثا حدى با آن بعفى موانقم.

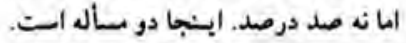

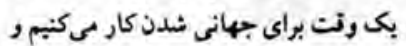

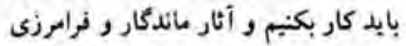

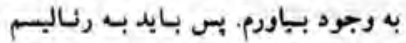

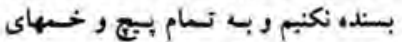

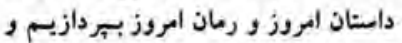

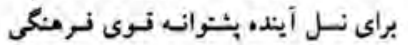

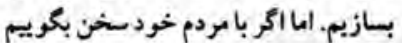
واكر بهرامب زبان ما را درك كتند، بابد

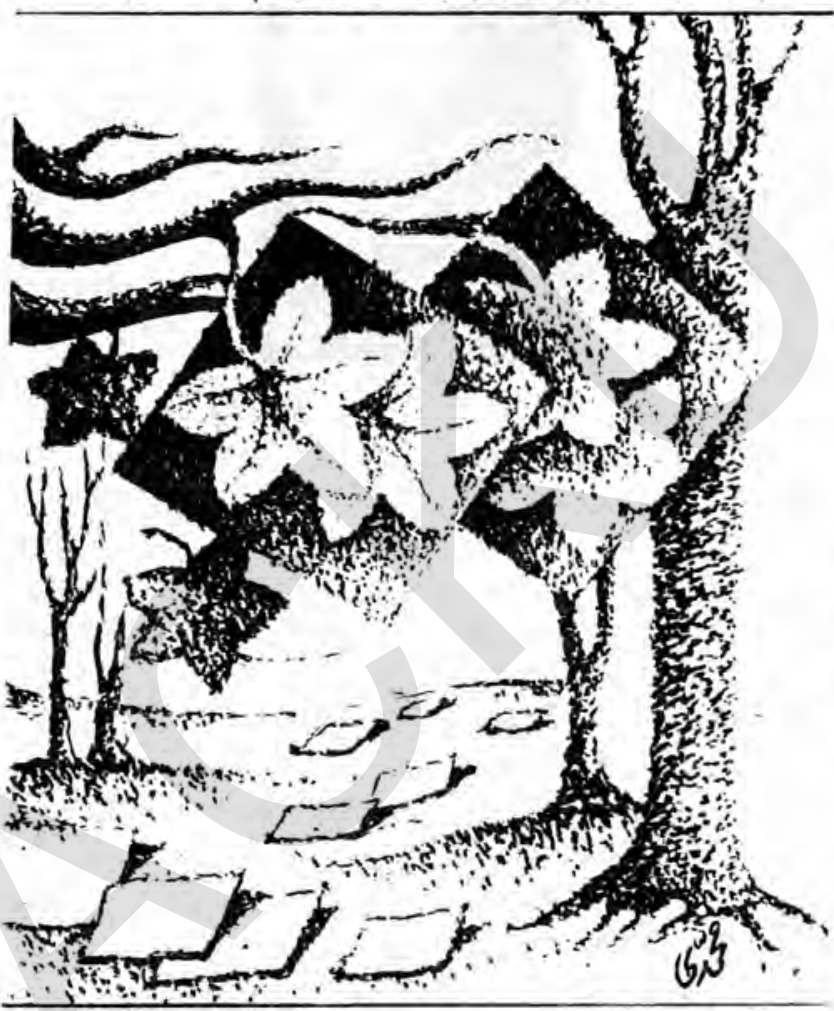

آثار رناليـنى به وجود آوريم ود در ايسن قالب كب بزنيم.

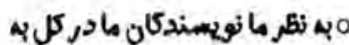

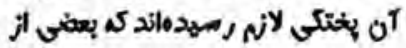

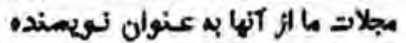

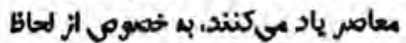

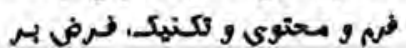

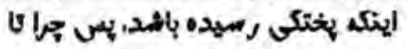

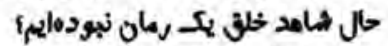
• اولاً در جامعن ما القاب ور عنارين

بسيار ارزان شيد،، نويسند. معاصر دجار

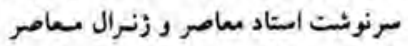

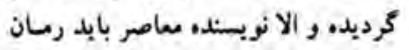

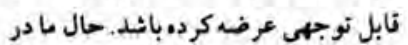

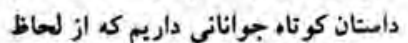

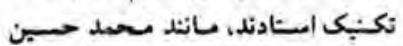

متفاوتى داريم و مر نويسند، هم نعايند.

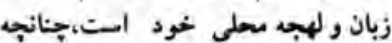

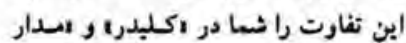

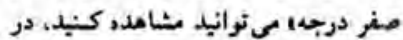

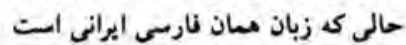

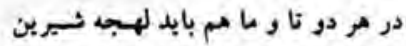

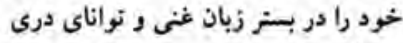
بالندكى دهيم.

0 مطبوعات مهاجر بم وجود أمد در

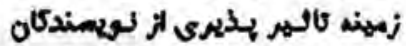

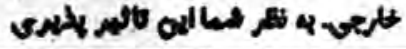

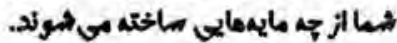

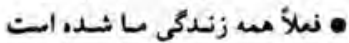

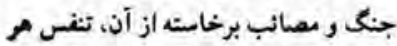

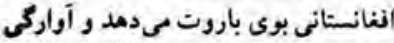

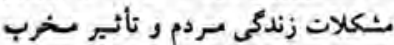

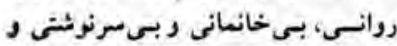

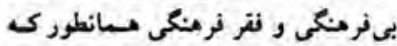

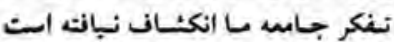

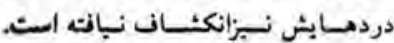

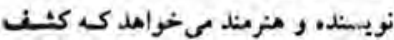
كند.

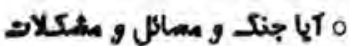

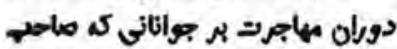

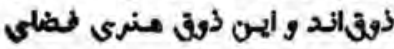

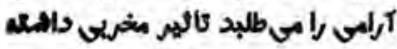
\{ats

• البـتـت شـامكارماى جـهانى در

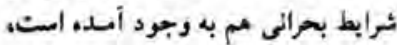

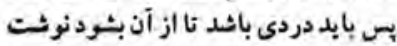

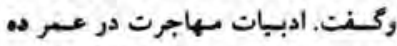

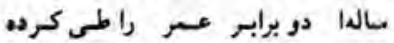
است، جــون حسرفى بـراي كـنتن دارد.

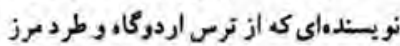

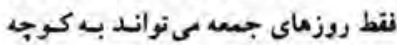

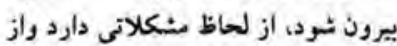

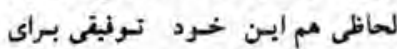

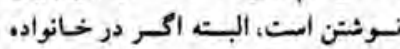
آرامترى زندكى دايت باثمد و البته روزنة

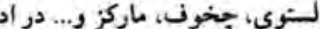

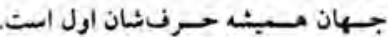
بكذربم از اينك تا بوده اين منر در شئرف

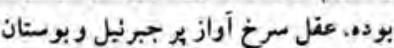

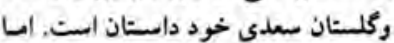
دامتان مدرن بـ ئكل كنـونى و انسـام

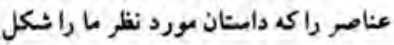

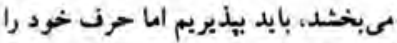

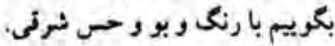

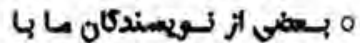

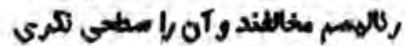

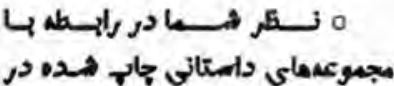

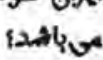

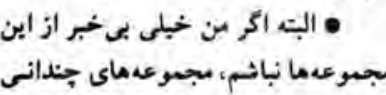

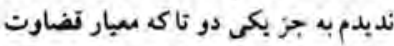

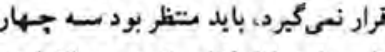
كنبم

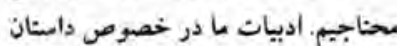

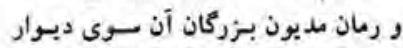

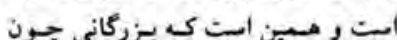

$$
\text { لازم امبت تا نفس بكثي. }
$$

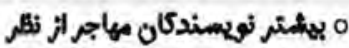

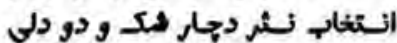

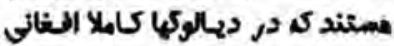

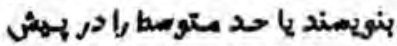

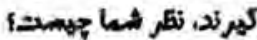
• البته من عرض كنم كن نثر جيزى لهري

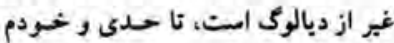

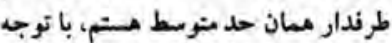

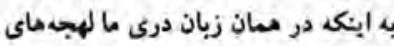


خير، شوى و ارنباط ببدا كنم. عساشن

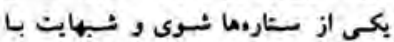

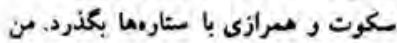

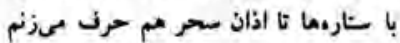

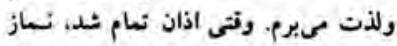

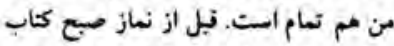

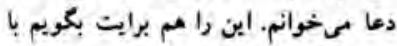

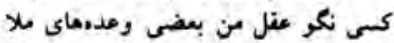

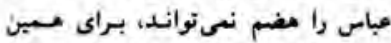

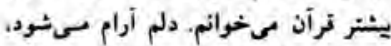

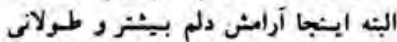

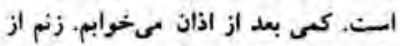

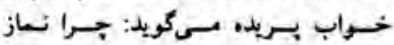

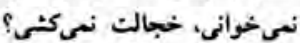

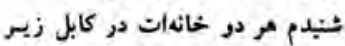

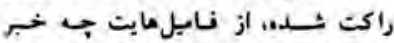
دارى؟ خوب از ابنك درذهايت را نائ.

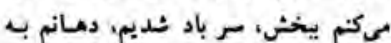

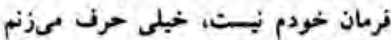

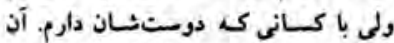

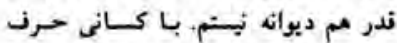

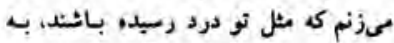

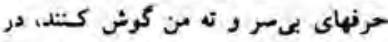

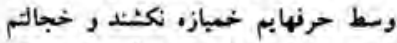

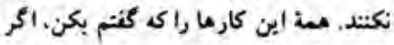

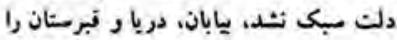

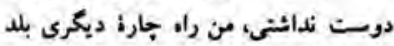

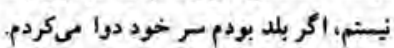

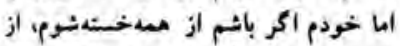

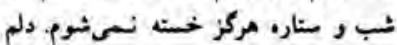

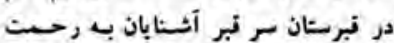

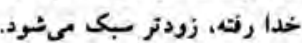

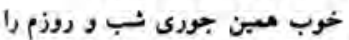

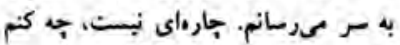
بايد سوخت و ساخت ديكر مانم

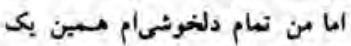

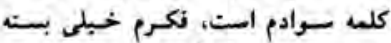

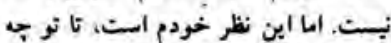

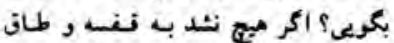

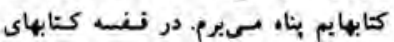

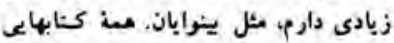

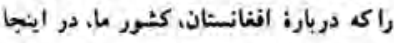

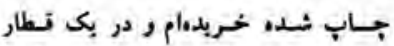

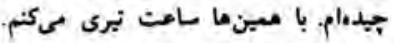

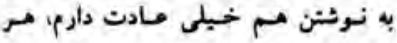

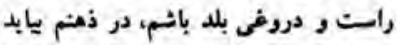

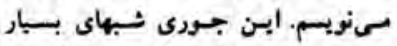

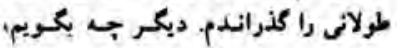

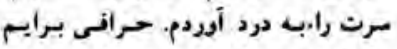

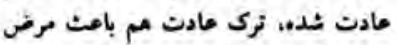

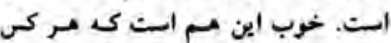

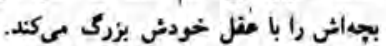

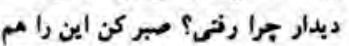

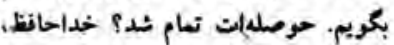

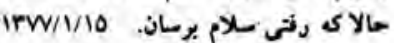

دـت مسدبكر در عذايم. به نظر خسودم

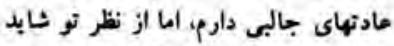

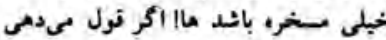

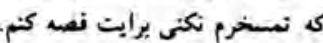

خوب از برادر كلان جه خبر؟ به خير

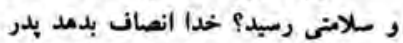
كلانهاى ما را از عقل ئان جندان استفاده

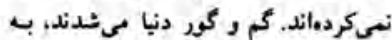

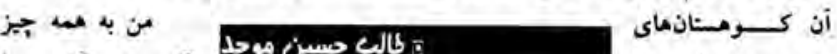

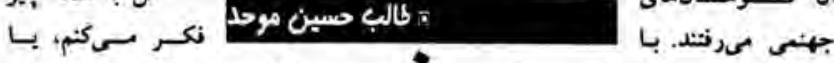

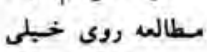

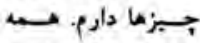

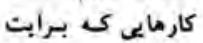

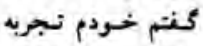

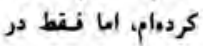

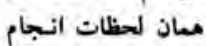

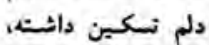

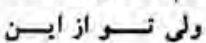

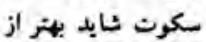

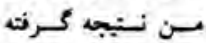
باثى. داشتم برابت بريت

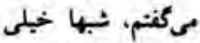
آهسته بثل يك دزد حســـنهاى از خــانه

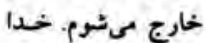
نكثد زنم خبر شود و

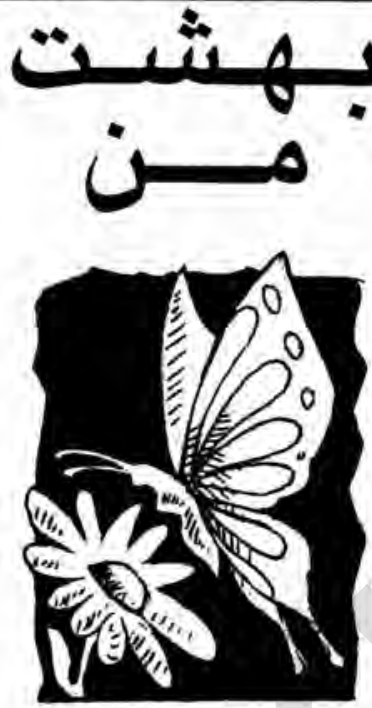

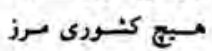
ندأريسم. خـدا بـرادر كلان شسار. رحت مثت

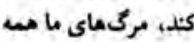

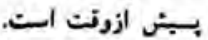

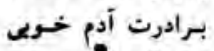

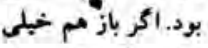

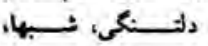

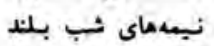

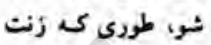
نغهمد، برن را روشن

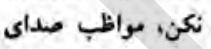

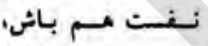

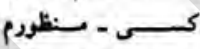
بسبماى كوجكت

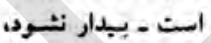
الا لكرماى بلى به سرش خواعد زد كي

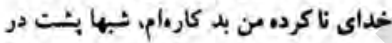

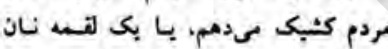

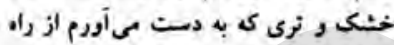

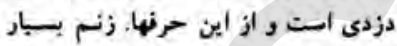

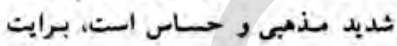

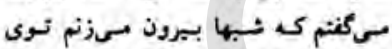

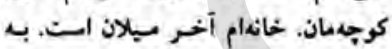

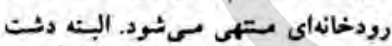

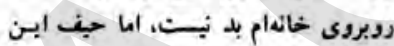

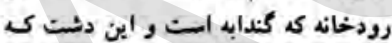

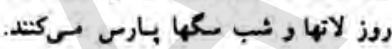

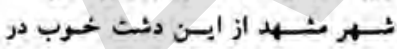

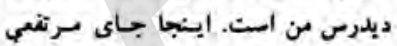

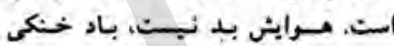

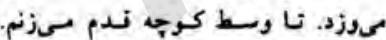

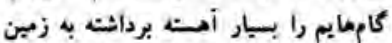

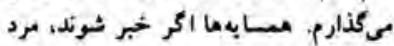

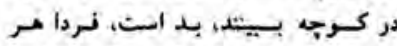
جيزيناذ كم شند مرا دزد سمىكيرند. البـه

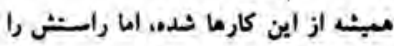

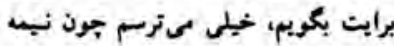

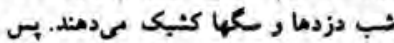

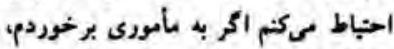

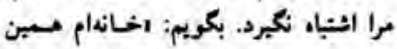

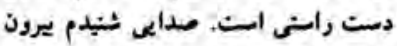

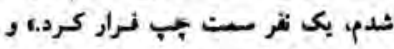

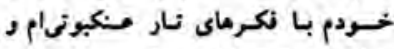

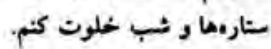

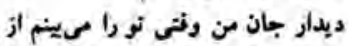

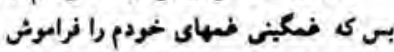

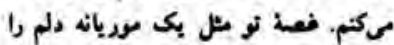

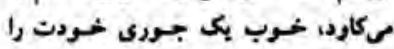

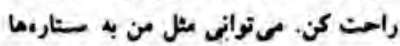

مىدانمى، من كامى مثل تمو دلتسنب

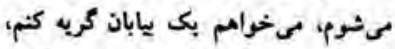

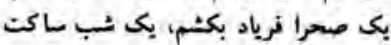

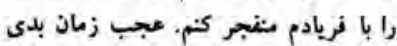

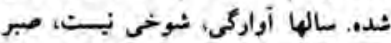

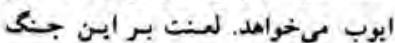

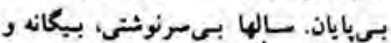
موجود اضانى براى مردم.

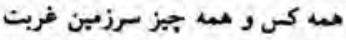

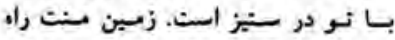

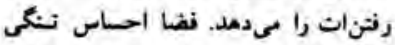

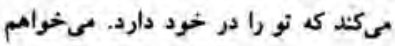

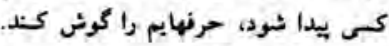

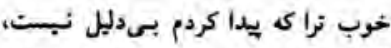

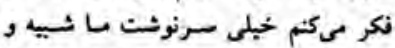

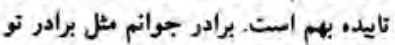

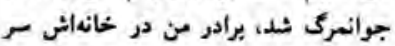

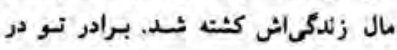

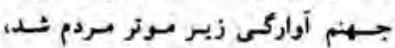

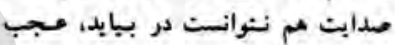
بدثنانس أدمها مستخم، راستى نو حوميله

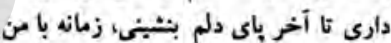

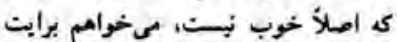

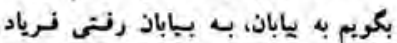

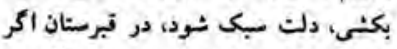

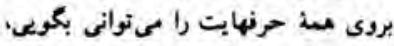

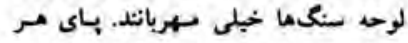

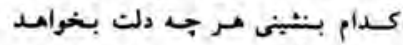

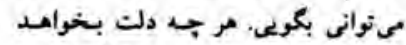

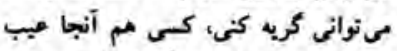
نمىكيرد. نبرستان اصلاً بجائ كريه كردن مئن

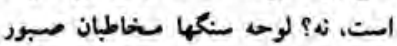

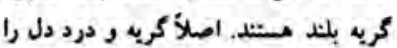

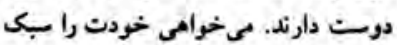

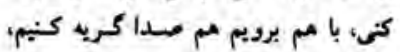
جطور است، موانقى؟ برى

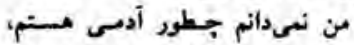

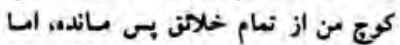

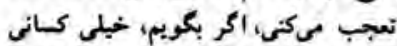

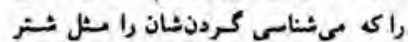

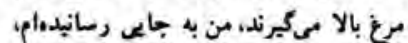

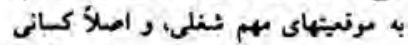

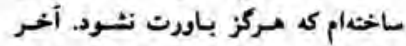

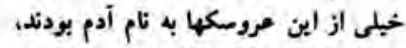

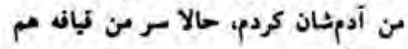

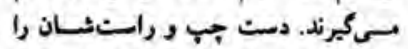

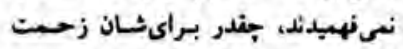

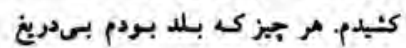

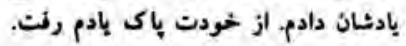

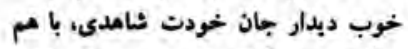

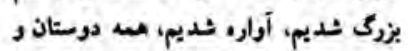

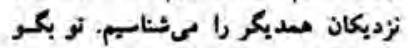

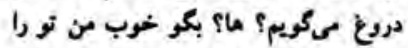

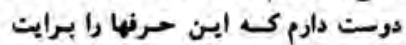

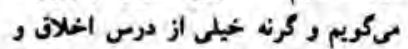

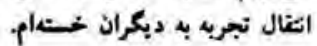


آن حصار و برج و بار و بام تو ئو

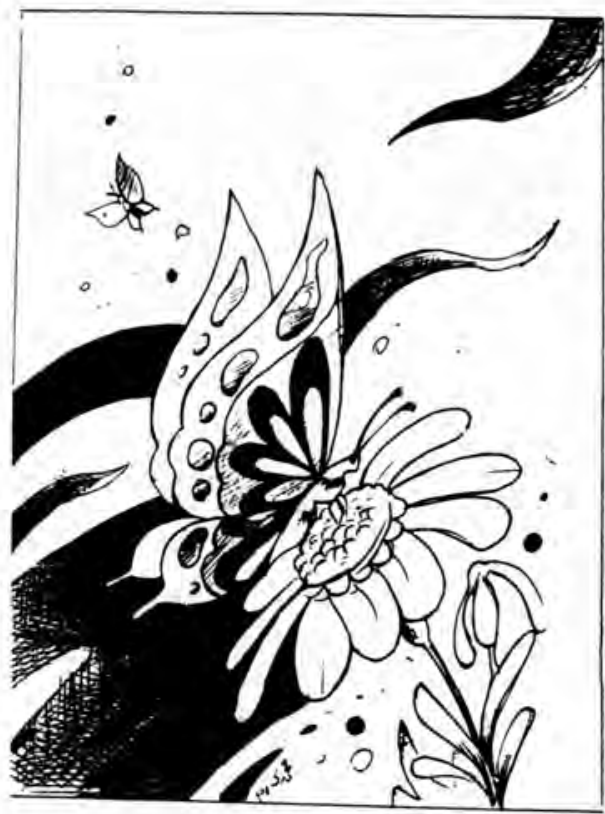

هزار فاخته خاموش

هينا نصر

دركــوجة بــاريكى و تــنهايى خويش روزى هزار زنجره عبورم روزى هزار فاخته خاموشم عزيم ينجرئ من به كبود آسمان شبيه مىشود

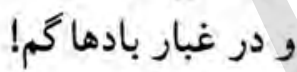
من همان ساحلم كه دريايش خاموش ماند از هياهوى رسيدن همان عبورم كه كامهايش صدا ندارد همان عقربههاى ساعت كه عقب مىروند

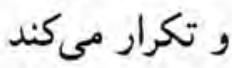

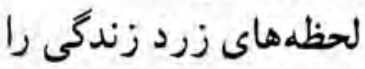
بى هيج خاطرهاى بى يقيج بهارى!
كاش مىشد بوسه بر خاكت زنم

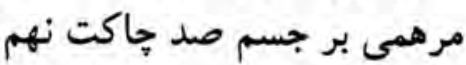
ايى برادر ساز و برى ديخ ديخرى زندگى يا مرگ، مرگ ديخرى

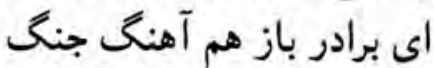
قصهاى اما به آئين تفنگ آهن اي برادر با خودت انديشه كن ائن قد بر افراز و صبورى بيشه كن باز كن بند ستم از دست و وبا تا شوى اي دوست آزاد و رد رها

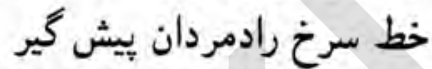
انتقام خون طفلانش بخير

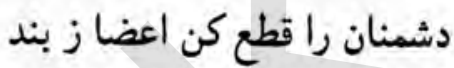

تا شود بر بهنهُ تاريخ يند

$$
\text { مدارا }
$$

بيا تاكه از عشق نجواكنيم ره و رسم ديرينه احيا كنيم سرود (بحبل الهيى) را بيا بخوانيم و تفسير و معنا كنيم بيا تاكه يك قطره باران شويم سفر تا به اعماق دريا كنيم بيا تا به پاس طلوع سحر دل خود ز ظلمت مبر اكنيا بيا تا كه آينهُ هم شويم در آن درد هم را هويدا كنيم شتويم

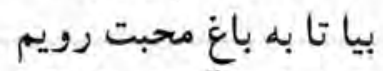
صفا را در آنجا تماشاكنيم كُره باز از دست و از بـ با بنديم بيا در شكوه بهاران عشق إنق كل لاله را فرش صحراكنيم

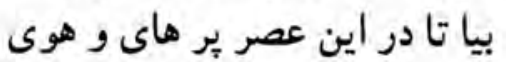
صميمانه با هم مدارا كنيم

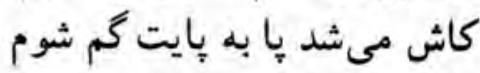
ناله دلهاى اين مردم شوم بـ بايت

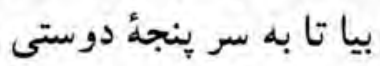

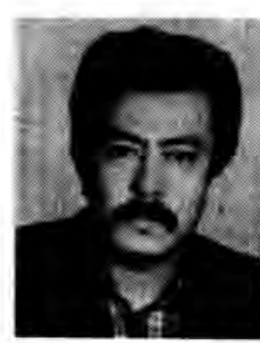

دو شــر

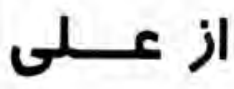

اكبر نجوا

مزار عشق

بشنو از من قصةٔ اين ايل را را رائراي ماجراى زادة هابيل را

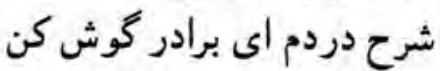
جرعهاى زين جام ماتم نوش كن يكى نيستان ناله دارم در كلو جام

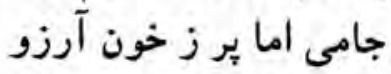
بشنو از من داستان جهل و وجنى آرزي

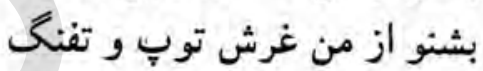
شد مزار عش بِامال جفا

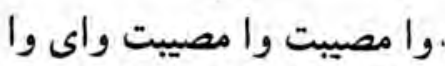
شهر مولا شد اسير طالبان دشنهان بر سينة خورد و كلان طالبان فتنه حاكم گشتهاند يشتهها از كشتهها انباشتند يك شهيدستان شهيد نوجوان

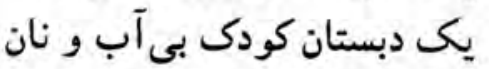

جادها بِر گثته از بيم و بلا

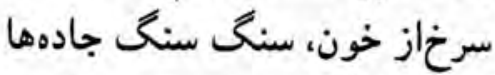
كوجههامان بوى غربت مي دهد

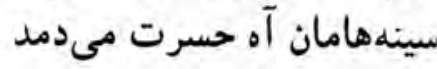
سروها اينجا ز سر افتادهاند

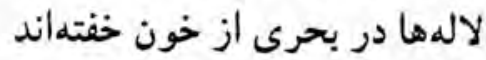
قامت (بابا)، از اين ماتم خميد الدان جان ياميرش هزاران زخم ديد رود كابل اشكى ماتم زاد شد آسمان تا آسمان فرياد شد آداد اي اسير بند ارباب بلا اي شهيدستان من اي كربلا

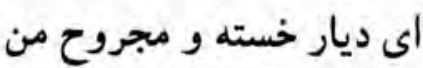
جان من قلبم الا اي روح من يس كجا شد باستانى نام تو 
تشدم نقط از او تشيدم كى بابغض عرنت

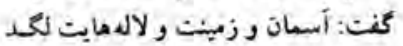
مال شدءاند.

ولى باور نكردم جراكى تسو اجسازئ

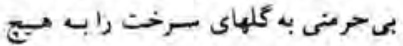

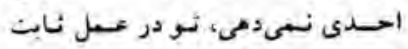

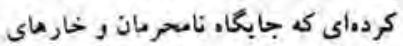

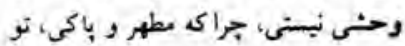

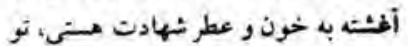

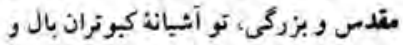

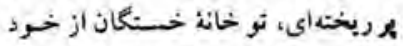

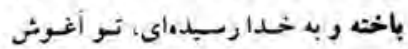

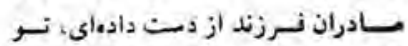

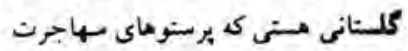

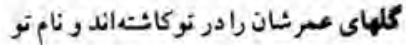

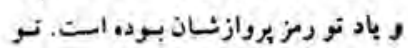
كلثن كلهاى لالمائ و در تو ويرانة دلها

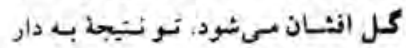

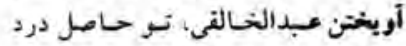

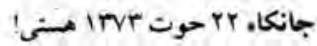

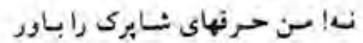

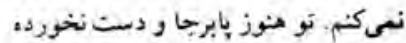

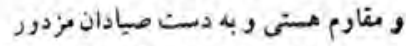

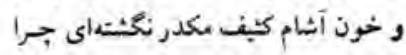
كل ايسان دارمبد طاهر و منبرك بودذ نو ور

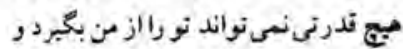

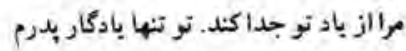

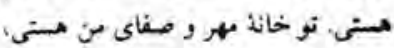

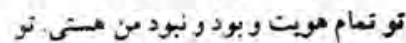
معل وجود من مستى.

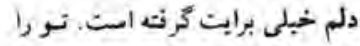

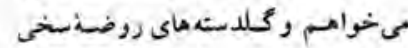

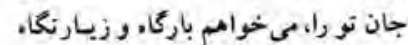

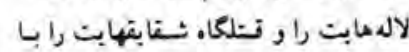

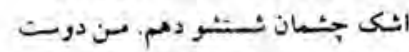

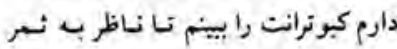

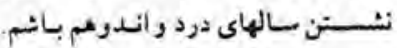

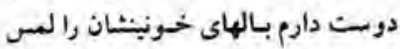

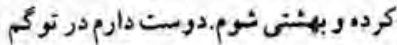
تومي وكتدكانم را يداكنم.

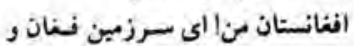

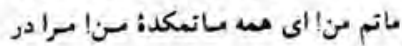

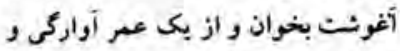

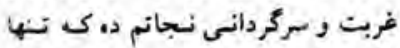

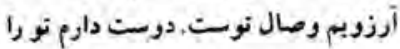

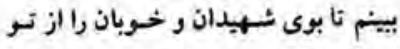
التشسام كتم. بس مرادرياب الى خـاكي مبرى كربلاي حسينيان زمانم.

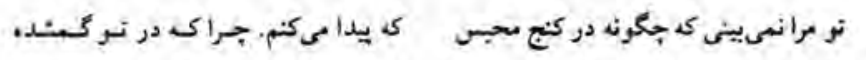

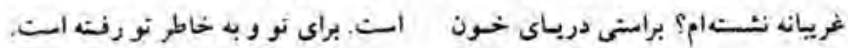

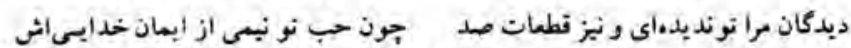
ماحر
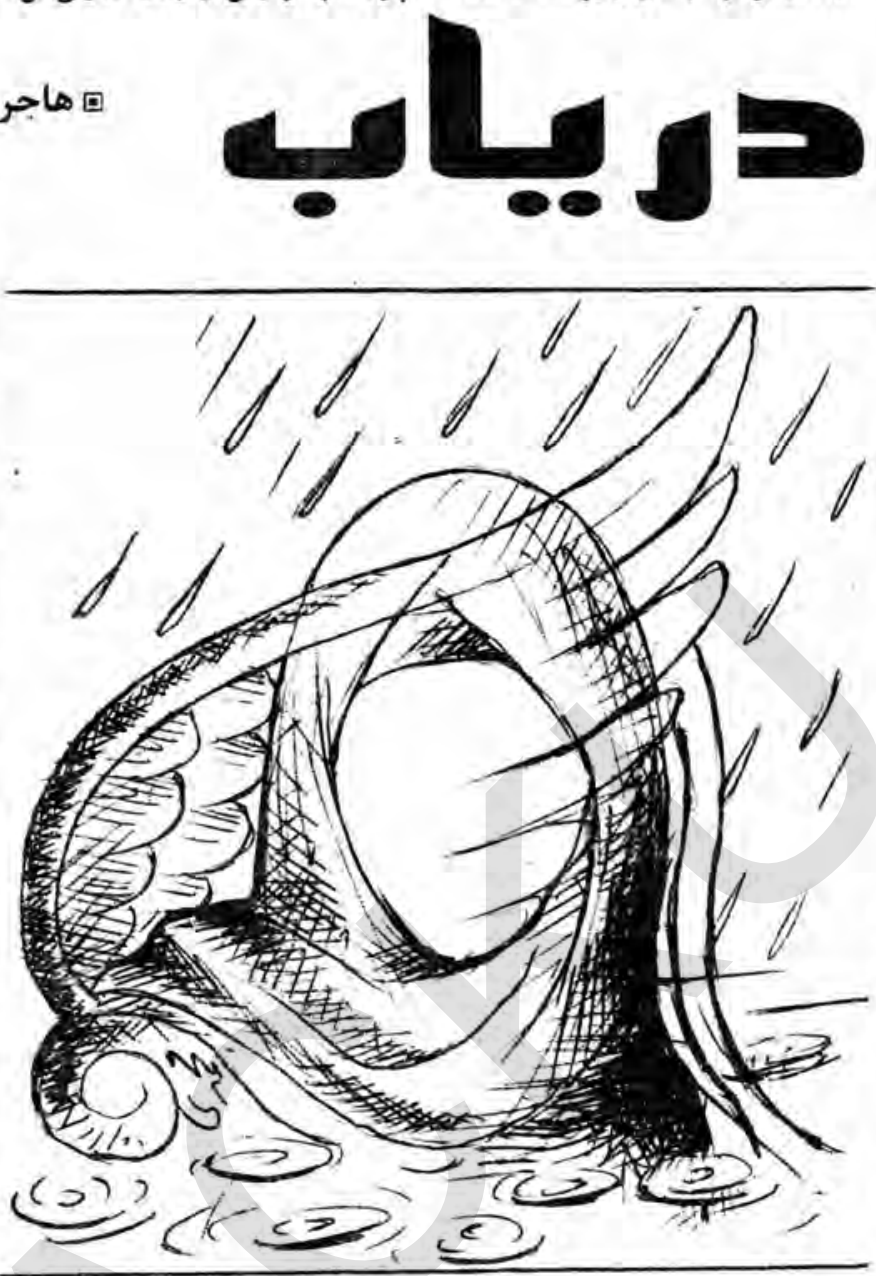

بود ر غم اركه در دارا بودن ايت مسفت

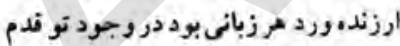

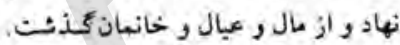

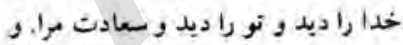

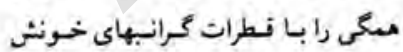

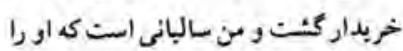
مى جويم و نمىيابم.

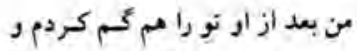

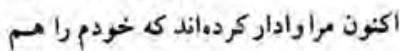

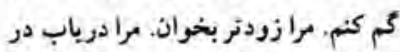

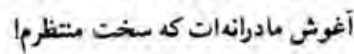

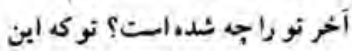

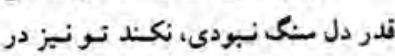

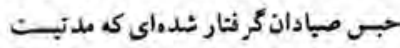

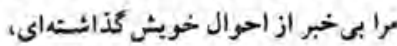

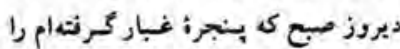

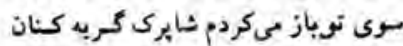
بيغامى داد ورنت، ولى خـوب منتوجه
بارئ قلبم را بر در د ديوارت ناظر نبسنى

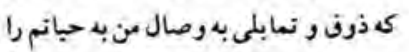
درخويش نشان نسى دمى، توكم ابشكونه

نبودى!

مرادردى جـانسوز و طسافت فرسا

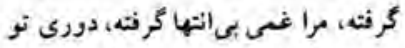

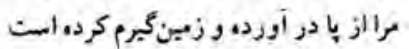
و جز حسرت ديدارت نسمىتوانسم جسيز ديخرى به تلبم حكى حنم.

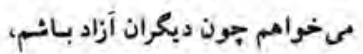

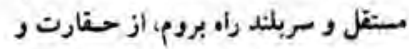

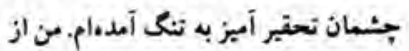

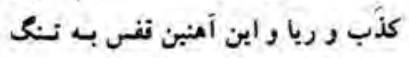
أمدهام من از نبئترماى زمر آلود تومين

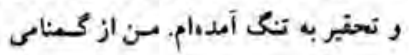
بدر و سالهاى انتظار بـ تنك آمد.ام.

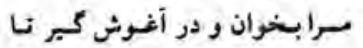

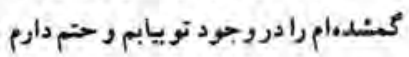

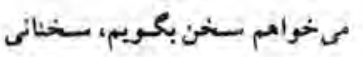

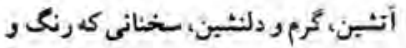
بوى ثجرت و تنهايع دارند. أما حرن دل

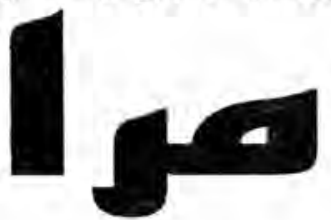

رابه مر كسى گفتن روانيست ونعى نوانم دل لبريز از حرفم رانزدكـى تهى كتم و ميثن در سكوت سرد سابيماى تنهايق مر به ديوار غربت نـرم نـرمى آسسعان خونين دل عنتى بـاريدن مسكند. در دل

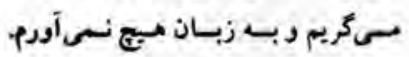
عتربمافى ساعت نكران و سريع مىروند

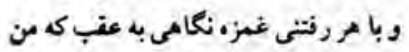
ماند،أم تها ميكتيد و دعوتم به برخاستن

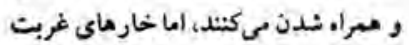

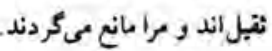
جشهان بارانى من به آندوردستستها

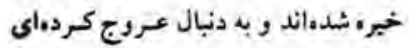

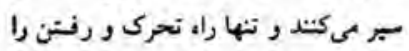
در دعوت تو مي بيند. الى باكترين سرزمين آسبا، الى

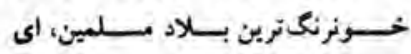

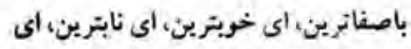
قلب أسيا، الى سرزمين خون و حماسسابلي اي بزرى مادر من واي ميهن من إمن به تو

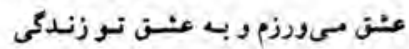

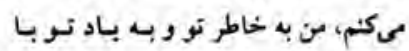

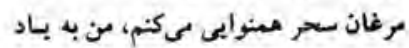

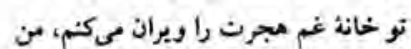
براي تو بيغرارى مىكنم. وطن در خون شناورم| جرا آغـوش نمى جراصدايـم نسىىنى تـا از بسباء جـال تنهايى بدر آمده و بر سبز نزاران تو تدمب آيا تو صداي ضسجهاى بئهانى مرا

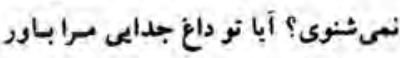
ندارى؟ آبا مرانسىخواهم؟ بنى كـ تمام

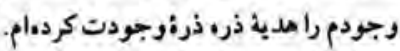
من تمام مستـثى خسويش رابـ بـاي تـو

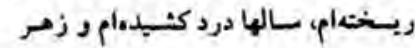

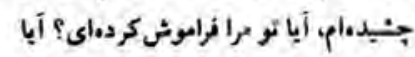




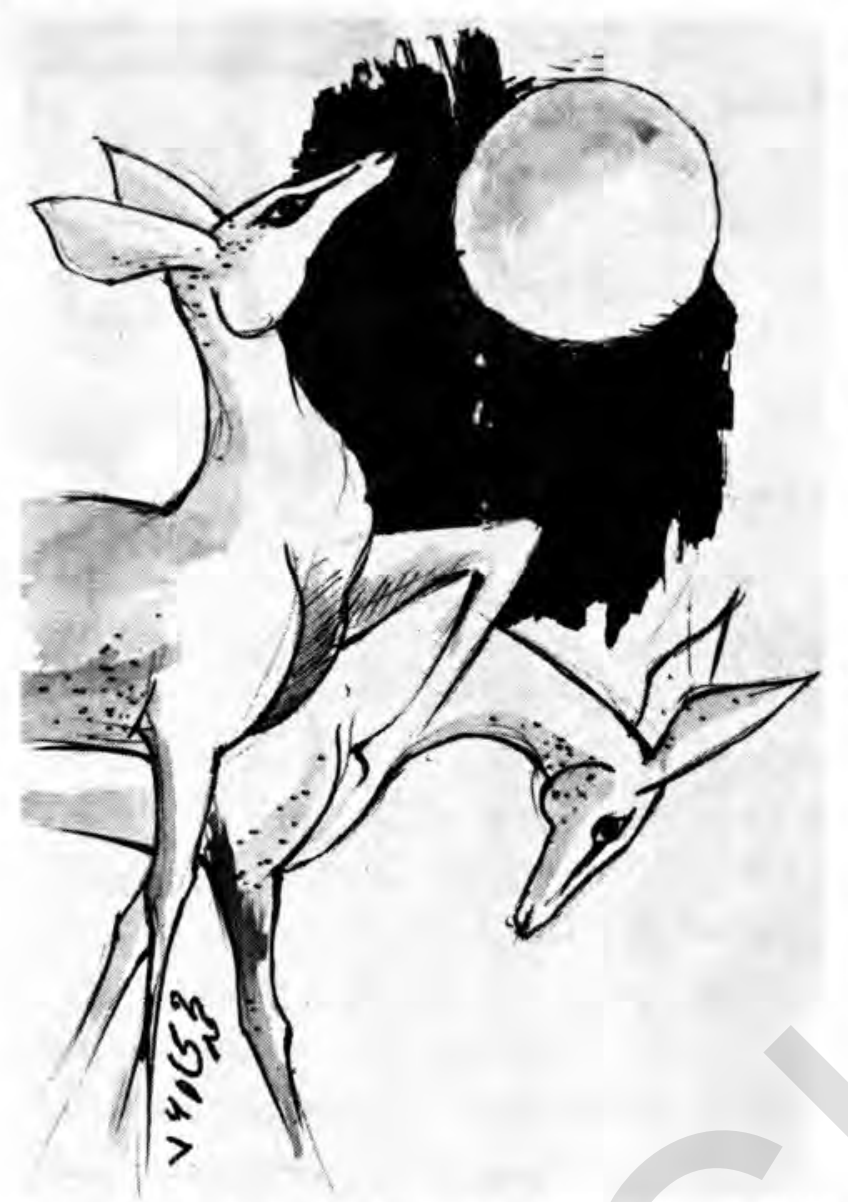

كاربرد جند دالر را مم ندارد. درميت بـ مهان انداز.كى يول افغانى، ناجل ثـده.

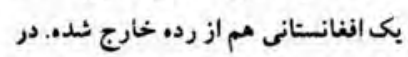

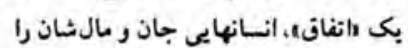
از دست مىدمند، آنكا. مىكويند: ديك

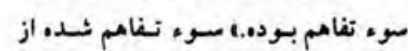

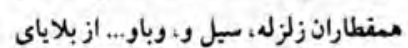
طبيعى كه هيج كسى مسؤولبت آن را بـ

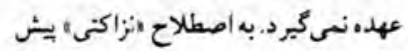

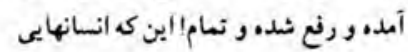

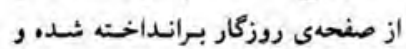

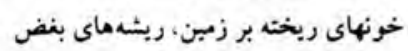

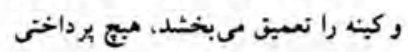

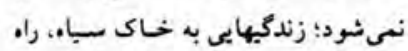

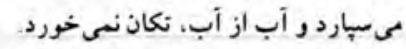

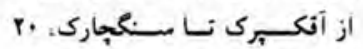

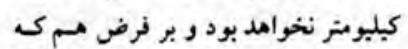

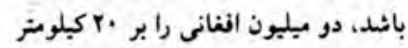

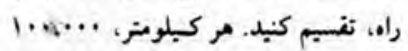

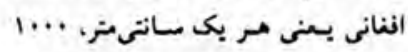

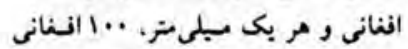

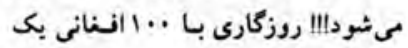

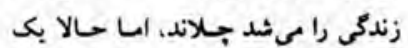

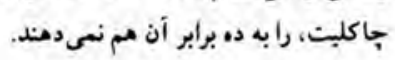
در اختبار اجعيت، است. از طرفى مم

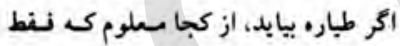

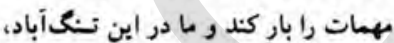
ادامس يدا كنيم. بك بند.ى خدا از تاجيكهاى امرخ

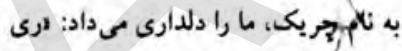

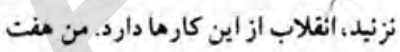

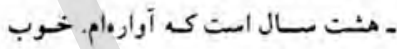
انقلاب است و... شسا اكر خواست باشيد.

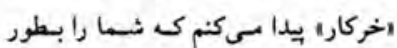

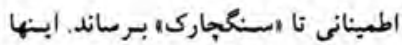

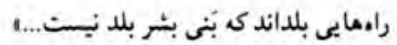

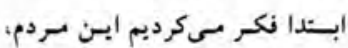

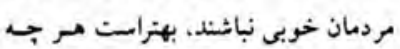

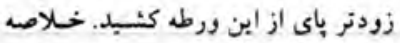

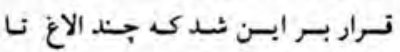
سنكجارك، كرايه كنبم. مس ربابه، الاغ، مبلغ دو مبليون و صد مزار انغانى، كرايه كرديم و توكل به خدا حركت.

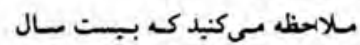
جنك، از اجهاد، علي شوروى سابق تـا

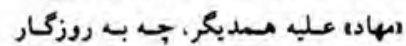

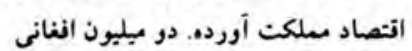

\section{قسم:ت سوم}

بإلهاى شناور

\section{انقلاب از اين كارها دارد}

در ممين لحظات، بكى نغر در حالى كى بكى از دوستان كفت: كمانم روى تشك،

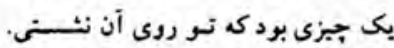

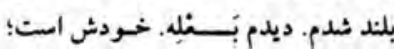

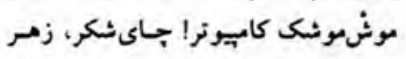

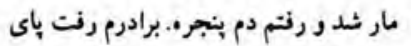

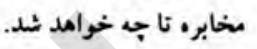

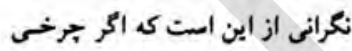

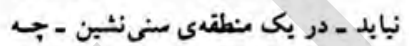

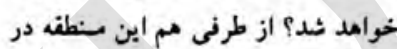

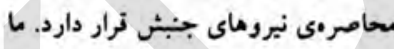
هم با جرخى اي أمدهايم كه حامل مهمات جرات

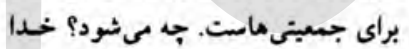
مى داند.

تازه، شانسى كه آوردهايم اين است

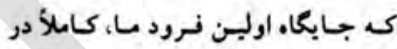

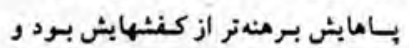

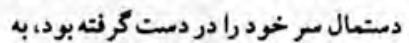

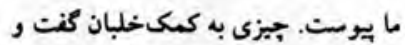

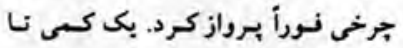
تستى به تشويشم اضافه شد. از بـنجر.

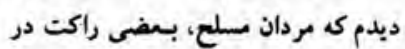

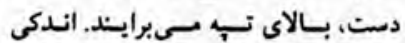
نحذثـت و در محل ديكرى أسماذ رابـ زمين مىبخشيديم. آنقدر مردم اطرات

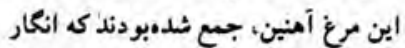

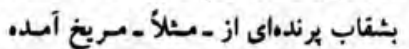
باثشد. تراكم جمعيت ـكـ آن مسردم نسيز

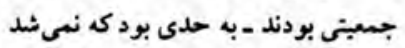
ههمات را بايين كرد. خواستبم بركرديم مزارثريف. اما خلبانها موانفت نكر دئد.

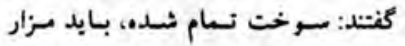

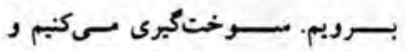
برمىكرديم. ما بـ زمسين خـود آمـديم و

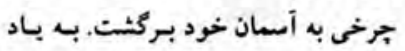

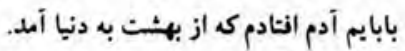
بادش بخير! در نزدبكترين سراى - بـ اصطلاح خارجكى اش امـله ــ نـرود آسـديم و

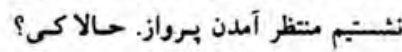
بـمان تـا رأسمان در جثـــهابت نتخم

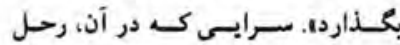

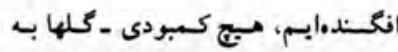
روى تان ـ از اسطبل ندارد. آنقدر كثيف

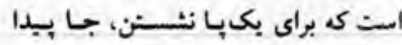
نسمىشود. دو - مس تـالحساف و تشكي بازنشسته، روى فـرنهايى كى مـالها از

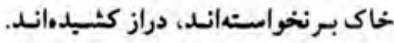
جاشت شد و جاى شيكرى بايد، كى ازكتل

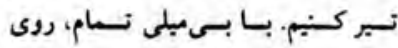

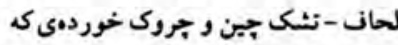
مثل يثمانى صاحبخانه بى حساب بود،

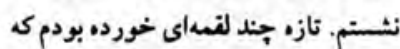




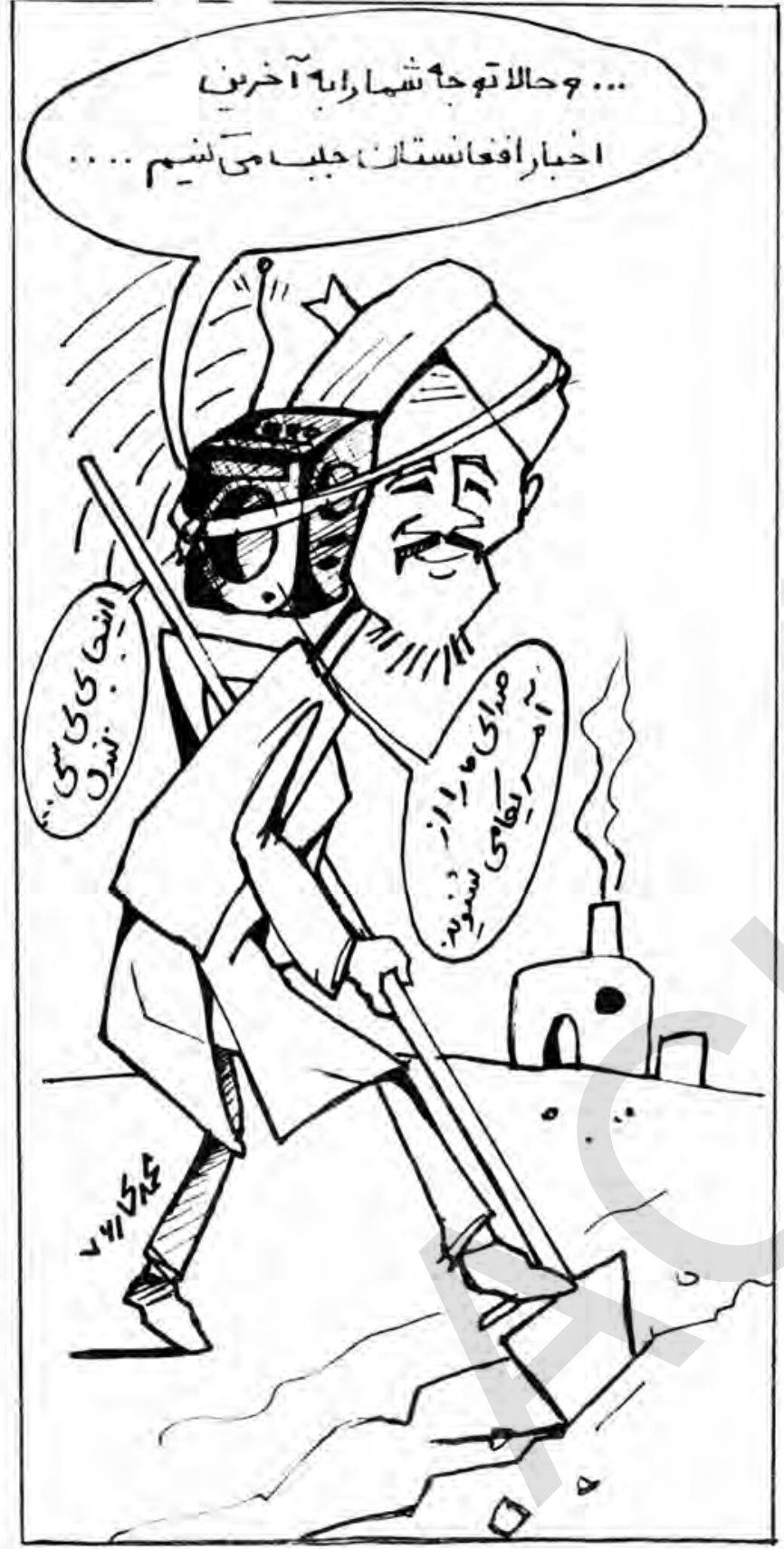

داشت و ده دكان خـود هـم آلـم

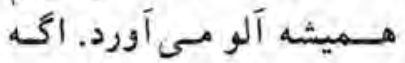
ترسان مىكدى كه بـبختشي اردي توت دارى، مئى مئت نه جان بـان بــيادر آلو اس. جـهار ميغز

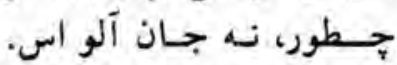
بالتى قلمى دارى، نـه جـان آلو اسب!

$$
\text { ترتيب انتشار: }
$$

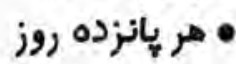
• نشانى بستى ايران - قم، ص. نهي rVIAO/RFG|
ـ ـ كَندافى!!

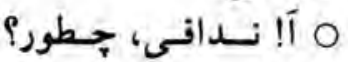
كدام كار بد خو نيس؟ إيستو

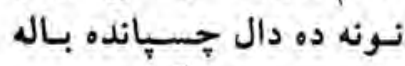

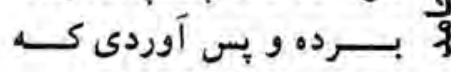
نزديك زاره كفك ما ساخته ـ ـنه! مخم قواره تان نداف والى مالوم نمى شـه. نام خدا تــوارهتـان آدمـاى فـاميده وارى مالوم مىشه، بـخيالم كه مزاق مىكنين. O برو بشت قواره نيخرد،

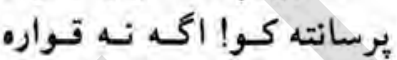
خودتام از خبرنغار كده... اينالى يك جيزى گفته بودمب،

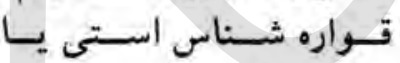
خبرنغار؟! ـ نظر تان راجع به نشريـ ها جـيس؟ O قند بـيادر اي نشيـريه خو شكر نو برآمده مه تانوز

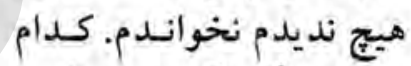

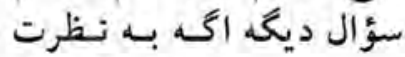

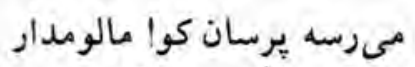

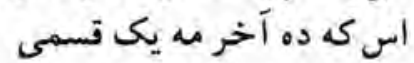

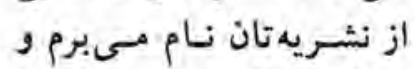

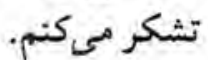
ـ ديزانيش جطور اس؟ م ديزاين جهـ ـ همى نشريه ره مى دمث.

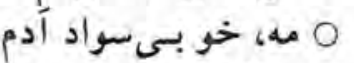

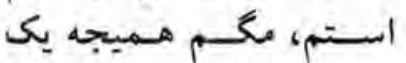

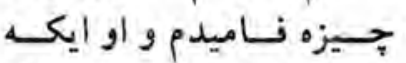
خودت نـام خـدا ايستو يك اونى رايوزتر صادق استى كه نغو

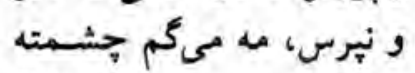
صدقه كه همى سؤ الت نقط ده باره نشريه خـودت اس.

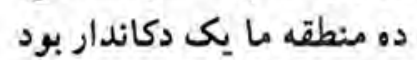
خودش آلوى بخارا دوست دئ داندار بود

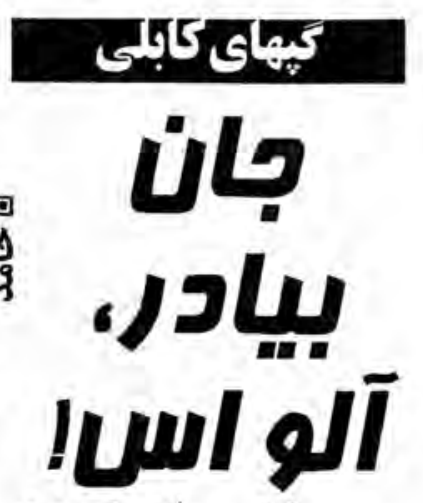

- ببخشى بيادر خـودت نو آملى بخير؟ م ازكجا؟ - از وطن مآ، يكى دو روز ميشه

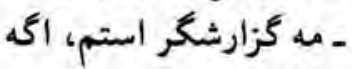
اجازتان باشه يك مستصاحبه

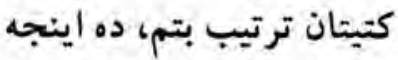

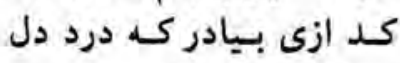

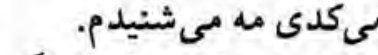
O بـرو كـدى كـدام آدم مديلم معروف و معتبر مصاحبه كو

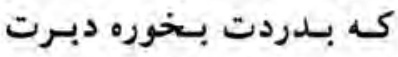

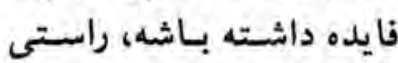
نغفتى از طرف كه مصاحبـ مىكتى؟ ـ مه از نثريه.... استم.

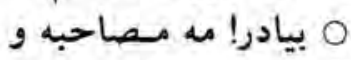

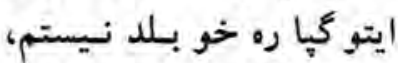

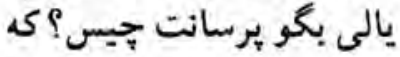
ده نشه خودت خار نسخوره! ايتو يك جوان معقول ده نظر ميايى. - بيسار تشكر، نمى فامى جه تسمى از خودت تشكي

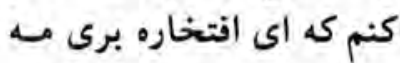

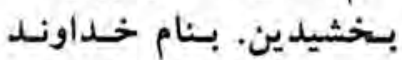
بخشنده مهربان. اول خودئ برى خوانندكان مارفى كنين! م نام مه شكـور اس، از

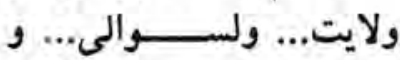
قريه... استم، ده افـغانستان ندافى ميكدم! 